\title{
SEARCHING FOR SOLUTIONS IN AQUACULTURE: AQUAPONICS
}

Vladimir Radosavljević ${ }^{1^{*}}$, Miroslav Ćirković ${ }^{2}$, Dragana Ljubojević ${ }^{2}$, Dobrila Jakić-Dimić ${ }^{1}$,Zoran Marković ${ }^{3}$, Jadranka Zutić ${ }^{1}$, Vesna Milićević ${ }^{1}$

${ }^{1}$ Department of fish diseases, Institute of Veterinary

Medicine of Serbia, Belgrade, Serbia

${ }^{2}$ Scientific Veterinary Institute "Novi Sad", Novi Sad, Serbia

${ }^{3}$ Faculty of Agriculture, Belgrade

\begin{abstract}
Aquaponic production combines intensive production with waste recycling and water conservation. Aquaponic join recirculating aquaculture with hydroponics to use nutrient waste from aquaculture as an input to plant growth. Traditional aquaculture systems treat or dispose nutrient-rich wastewater. In aquaponics, the waste products from the fish are converted by a bio-filter into soluble nutrients which are absorbed by the plants, and allow "clean" water to be returned back to the fish. Thus, it produces valuable fish protein with a minimal pollution of fresh water resources, while at the same time producing horticultural crops. Fish in aquaponic production systems can be raised in ponds, tanks, or other containers. Plants are grown separately in hydroponic tanks, submerged in water but suspended in gravel, sand, perlite, or porous plastic films, as well as on floating rafts. Systems vary greatly in design and construction, but most perform the following key functions: finfish and plant production, removal of suspended solids, and bacterial nitrification. This review discusses applications, effects and perspective of aquaponics.
\end{abstract}

Key Words: fish, aquaponics, aquaculture

${ }^{1 *}$ Dr sc. Vladimir Radosavljević, PhD, DVM, Institute of Veterinary Medicine of Serbia, Department of Fish Diseases, Vojvode Toze 14, 11000 Belgrade, e-mail: vladimiradosavljevic@yahoo.co.uk 


\title{
U POTRAZI ZA NAJBOLJIM REŠENJEM: AKVAPONIKA
}

\author{
Vladimir Radosavljević1, Miroslav Ćirković ${ }^{2}$ Dragana Ljubojević ${ }^{2}$, Dobrila \\ Jakić-Dimić ${ }^{1}$, Zoran Marković ${ }^{3}$, Jadranka Zutić ${ }^{1}$, Vesna Milićević ${ }^{1}$ \\ ${ }^{1}$ Naučni institut za veterinarstvo Srbije, Beograd \\ ${ }^{2}$ Naučni institut za veterinarstvo "Novi Sad", Novi Sad \\ ${ }^{3}$ Poljoprivredni fakultet, Beograd
}

\section{Kratak sadržaj}

Akvaponika kombinuje intenzivnu proizvodnju sa reciklažom otpadnih materija i očuvanjem vode, i povezuje akvakulturu sa hidroponikom u cilju korišćenja hranljivih materija iz akvakulture za rast biljaka. U tradicionalnoj akvakulturi, otpadna voda bogata hranljivim materijama se ne koristi. U akvaponici, produkti nastali prilikom gajenja riba se pomoću biofiltera konvertuju u rastvorljive materije koje biljke apsorbuju, a "čista" voda se vraća ponovo u proizvodnju. Na ovaj način se omogućava proizvodnja visoko vrednih animalnih proteina, uz minimalno zagađenje vode, dok se istovremeno dobijaju proizvodi hortikulture. Postoji veliki broj sistema za gajenje, različitog dizajna i konstrukcije, ali se svi baziraju na zadovoljavanju ključnih funkcija: proizvodnji riba i biljaka, uklanjanju rastvorenih materija i bakterijskoj nitrifikaciji. U radu su prikazani primena, efekti i perspektive akvaponike.

Ključne reči: Akvaponika, akvakultura, ribe

\section{INTRODUCTION}

Aquaponics has been considered as a sustainable agriculture system that amalgamates aquaculture and hydroponics in an enclosed symbiotic environment (Nelson, 2008). The word 'aquaponics' is derived from a combination of 'aquaculture' and 'hydroponics', and refers to the integration of hydroponic plant/vegetable production with aquaculture. It is a bio-integrated system linking recirculating aquaculture with hydroponic production of plants such as vegetables, culinary or medicinal herbs. Aquaponics may provide an effective and efficient means to provide both animal protein (fish) and mineral and vitamin sources (fresh vegetables) to populations where water/and or fertilizer resources are limited with a minimum of environmental pollution.

The basic principals of aquaponics is that fish are fed "waste plant and animal material", which they convert into protein. The waste material from the 
fish is then used by plants as the nutrient source, and the water is then recirculated back to the fish tank. An essential component of this is a biofilter (between the fish and the plants) which essentially comprises bacteria which converts the waste products from the fish into soluble nutrients for the plants. An absolutely critical component of this is the conversion of urea (excreted by the fish) into nitrite, and then nitrate because high levels of urea in the water are toxic to fish. The solid waste (fish faeces and unconsumed food) is usually filtered off and converted into soluble nutrients in a separate bypass.

\section{Design}

Aquaponic systems are usually designed as an enclosed recirculating system, but a few systems can be open, depending upon environmental factors. Fish or other aquatic organisms are reared in tanks and excrete nutrientrich waste or effluents into the water. Metabolic byproducts excreted by fish, unionized ammonia NH3-N, ionized ammonia NH4+-N, or combined equal Total Ammonia Nitrogen (TAN) are oxidized and broken down into nitrite (NO2 --N) by nitrifying bacteria of the genera Nitrosomonas, Nitrosococcus, Nitrosospira, Nitrosolobus, and Nitrosovibrio. Genera that oxidize nitrite to nitrate (NO3--N) include Nitrobacter, Nitrococcus, Nitrospira, and Nitrospina (Timmons and Ebeling, 2007). These nitrifying bacteria are also known to be light sensitive (Yoshioka and Saijo, 1984). Mineralization also occurs, releasing essential inorganic nutrients into the water for plant uptake (Timmons and Ebeling 2007). These dissolved nutrients accumulate and reach concentrations equal to hydroponic nutrient solutions (Timmons and Ebeling 2007). The water is continuously circulated to hydroponically grown crops that absorb nontoxic nutrients from the water to fulfill growth requirements. The water is then circulated back to the rearing tanks where the process starts again.

There are multiple aquaponic system designs that have been analyzed and utilized for crop production. Depending upon the system scale there are five main components to an aquaponic system: rearing tank, solids removal, biofilter, hydroponic subsystem, and sump (Rakocy and Hargreaves, 1993). Some systems are able to eliminate one or two of the components, and scale and primary production focus are the key factors determining the system design. Some aquaponic systems are able to efficiently operate with the use of hydroponic subsystems acting as a biofilter. This is possible with the aid of media such as hydroton, pea gravel, and expanded shale (Rakocy 1984; McMurtry et al. 1990). Floating raft hydroponics also known as DWC, which utilize polystyrene sheets and net pots for plant support, may also provide adequate biofiltration provided the hydroponic subsystem is large enough (Rakocy 1995). When utilizing media within hydroponic subsystems, care must be taken to prevent an overload of suspended solids; therefore, media filled subsystems are not 
ideal for commercial scale production (Timmons and Ebeling 2007).

One of the most important components of an aquaponic system is the hydroponic subsystem: media filled, NFT, and DWC (Lennard and Leonard 2006). A media filled hydroponic subsystem contains a grow bed filled with a soilless medium for plant support.

Popular soilless media include hydroton (expanded clay pebbles), gravel, sand, and perlite. The NFT system consists of troughs that expose suspended plant roots (net cup) to a thin film of water. DWC is similar to the media filled subsystem but instead of using media in the hydroponic bed, a floating raft (polystyrene sheets and net cup) supports the plants.

Currently there are two main irrigation methods for hydroponic subsystems, flood and drain or continuous flow. Flood and drain system uses a siphon to periodically drain water when it reaches a specified level. A continuous flow system allows water to constantly run throughout the system (Rakocy et al. 2006). Lennard and Leonard (2006) found that hydroponic subsystem design and water flow have a significant effect on Green oak lettuce (Lactuca sativa) yield where media $>$ DWC $>$ NFT; NFT systems were $20 \%$ less efficient in nitrate removal. Lastly, producers should realize that differing aquaponic or hydroponic methods (system designs) do not alter the genotypic characteristics of plants. Production will not surpass genetic limitations regardless of growing techniques, and plants will reach peak production when optimum requirements are met (nutrient assimilation, light, temperature, etc.).

\section{Fish}

There is no real limitation on the types of fish which can be used. Today it is common to grow Nile tilapia (Oreochromis niloticus), channel catfish (Ictalurus punctatus), rainbow trout (Oncorhynchus mykiss), and various carp species (Cyprinus sp.), in aquaponic systems. Tilapia appear to be one of the most popular species of fish reared in aquaponic systems, because the warm temperatures for optimal growth of tilapia are also needed for the growth of plants (Rakocy and McGinty, 1989).

Other species of fish that are reared in aquaponic systems in include largemouth bass (Micropterus salmoides), sturgeon (Acipenser spp.), baramundi (Lates calcarifer), sunfish (Family Centrarchidae), bream (Abramis brama), pacu (Family Characidae), red claw lobster or crayfish, and ornamental fish such as angelfish (Pterophyllum scalare), guppies (Poecilia reticulata), tetras (Family Chiracidae), gouramis (Family Belontiidae), swordfish (Family Xiphiidae), mollies (Family Poeciliidae).

\section{Plants}

Common plants that do well in aquaponic systems include various lettuce 
(Lactuca spp.), tomato (Solanum spp.), spinach, and herb species including sweet basil (Ocimum basilicum), mint, watercress, chives, and most common house plants. Species of plants that have higher nutritional demands and will do well only in heavily stocked, well established aquaponic systems include tomatoes, peppers, cucumbers, beans, peas, and squash, among others (Rakocy, 1999).

Many of the fruit vegetables (tomato, pepper, cucumber, melon, etc) appear to require higher levels of nutrients in hydroponics, than the leafy vegetables. Nutrient wastes from tanks are used to fertilize production beds via the water. The roots of plants and associated rhizosphere bacteria remove nutrients from the water. These nutrients, generated from the feces of fish, algae and decomposing feed, are contaminants that could otherwise increase to toxic levels in the tanks. Instead they act as liquid fertilizer for hydroponically grown plants. In turn, the hydroponic beds function as biofilters, and the water can be recirculated to the tanks. Bacteria in the gravel and associated with the roots of the plants have a critical role to play in the cycling of nutrients; without these organisms, the system would stop functioning (Diver, 2006).

Aquaponic plants are subject to many of the same pests and diseases that affect field crops, although they seem to be less susceptible to attack from soilborne pests and diseases. Because plants may absorb and concentrate therapeutic agents used to treat parasites and infectious diseases of fish, these products cannot be used in aquaponic systems.Even the common practice of adding salt to treat parasitic diseases of fish or to reduce nitrate toxicity would be deadly to plants. Instead, non-chemical methods are used, ie., biological control (resistant cultivars, predators, antagonistic organisms), barriers, traps, manipulation of he environment, etc.). It also seems that plants in aquaponic systems may be more resistant to diseases that affect those in hydroponic systems. This resistance may be due to the presence of some organic matter in the water, creating a stable, ecologically balanced growing environment with a wide diversity of microorganisms, some of which are antagonistic to pathogens that affect the roots of plants (Rakocy, 1999).

\section{CONCLUSIONS}

Aquaponic system is advantageous compared to other agriculture production systems, and has become very popular today (Rakocy et al. 2006). Since aquaponic systems are designed as enclosed recirculating systems, their agricultural waste and environmental footprints decrease, compared to conventional agriculture practices. Furthermore, utilization of plants as a secondary 
crop reduces the pollution load (waste concentration) through nutrient uptake and assimilation (Timmons and Ebeling 2007). Nitrate accumulation has been shown to be reduced by $97 \%$ within aquaponic systems compared to regular recirculating aquaculture systems (RAS) (Lennard 2006). Since water within systems is recirculated, the quantity of water needed to run the system is minute compared to most fish and crop production systems. On average, $98 \%$ of the water in aquaponic systems is recycled for the duration of operation (AlHafedh et al. 2008). The periodical input of water is only necessary when too much water has evaporated from the system. Aquaponic systems decrease the amount of space needed to produce two crops at once. This allows plants and fish to be raised together within a relatively small environment.

Aquaponics can range from an in-home counter top system to large scale commercial systems. Additionally aquaponics on average utilizes less than $1 \%$ of land compared to conventional agriculture systems. Along with space, aquaponic systems use fewer resources than average crop and fish production systems due to symbiotic relationships (Treadwell et al. 2010). For example, aquaponics utilizes $90-99 \%$ less water than conventional agriculture systems. Also, carbon dioxide $\left(\mathrm{CO}_{2}\right)$ from fish rearing tanks can also be used to increase crop production within an indoor facility (Timmons and Ebeling, 2007). Furthermore, aquaponic systems can be deployed in various environments allowing for year round crop production, and potentially a closer farmer-toconsumer interaction. Lastly, successful aquaponic systems utilize secondary crops that are of economic importance or beneficial to the aquatic organisms being produced (Timmons and Ebeling, 2007).

As with all food production systems, there are a few disadvantages with aquaponic systems. First, the ratio of hydroponic growing area compared to fish rearing surface area is relatively large. Ratios have been used ranging from 1:1 to 10:1, which are dependent upon the scale of the system, primary species of focus, and space. Another disadvantage includes the labor involved with plant management. The majority of aquaculturists do not have horticulture experience or knowledge, so additional personnel is often needed. Furthermore, due to the close relationship between fish and plants within an aquaponic system, poor management practices can easily affect the sensitive system. Pesticides cannot be utilized within systems and thus, biological control or natural methods must be used to eliminate plant pests (Timmons and Ebeling 2007). When entering into a competitive market, aquaponic producers should evaluate competitors and their species of production. It has been stated that hydroponics can produce heads of lettuce cheaper than what aquaponic systems can produce (Ako and Baker 2009). Lastly, materials utilized for aqua- 
ponic production (hydroton, fish feed, etc) are not considered sustainable. For example, hydroton (clay) is mined from the earth, and fish feed may come from wild caught fisheries or commodity crops. These materials utilize nonrenewable resources for production and may also contribute to environmental pollutants.

\section{ACKNOWLEDGEMENT}

This study was financially supported by a grant from the Ministry of Education and Science of the Republic of Serbia, under the project TR31075, TR31011.

\section{LITERATURE}

1. Ako, H., and A. Baker.: Small-scale lettuce production with hydroponics or aquaponics. College of Tropical Agriculture and Human Resources, University of Hawaii at Manoa; Sustainable Agriculture SA-2 1-7, 2009.

2. Al-Hafedh, Y. S., A. Alam, and M. S. Beltagi.: Food production and water conservation in a recirculating aquaponic system in Saudi Arabia at different ratios of fish feed to plants. Journal of the world Aquaculture Society, 39, 4, 510-520, 2008.

3. Diver, S.: Aquaponics-integration of hydroponics with aquaculture. NCAT Sustainable Agriculture Project, ATTRA. 1-28, 2006.

4. Lennard, W. A., and B. V. Leonard.: A comparison of three different hydroponic sub-systems (gravel bed, floating, and nutrient film technique) in an aquaponic test system. Aquaculture International 14, 539-550, 2006.

5. McMurtry, M.R., P.V. Nelson, D.C. Sanders, and L. Hughes. Sand culture of vegetables using recirculating aquaculture effluents. Journal of Applied Agricultural Research, 5, 4, 280-284, 1990.

6. Nelson, R. L.: Aquaponic food production - raising fish and plants for food and profit. Montello, WI: Nelson and Pade, Inc., 2008.

7. Rakocy, J.E., and J.A. Hargreaves.: Integration of vegetable hydroponics with fish culture: a review. In: J.-K. Wang, Ed. Techniques for Modern Aquaculture. American Society of Agricultural Engineers: St. Joseph, MI; 112-136, 1993.

8. Rakocy, J.E.: A recirculating system for tilapia culture and vegetable hydroponics. In: R.C. Smitherman and D. Tave (Eds.), Proceedings of the Auburn Symposium on Fisheries and Aquaculture, Auburn University, Auburn, AL; 103-114, 1984. 
9. Rakocy, J.E.: Aquaponics: the integration of fish and vegetable culture in recirculating systems. In: M.C. Palada and C.C. Clarke, Eds. Proceedings of the 30th Annual Meeting of the Caribbean Food Crops Society, St. Thomas, USVI; 101-108, 1995.

10. Rakocy, J. E., M. P. Masser, and T. M. Losordo.: Recirculating aquaculture tank production systems: Aquaponics- integrating fish and plant culture. Southern Regional Aquaculture Center; SRAC Publication No. 454, 2006.

11. Rakocy James E and McGinty Andrew S.: Pond culture of tilapia, Southern regional Aquaculture Center. SRAC publication No. 280, 1989.

12. Rakocy, J.: The status of aquaponics, Part 1. Aquaculture Magazine 25, 4, 83-88, 1999.

13. Timmons, M.B., and J.M. Ebeling.: Recirculating Aquaculture. 2nd ed. Northeastern Regional Aquaculture Center. Ithaca, NY: Cayuga Aqua Ventures; 2007.

14. Treadwell, D., S. Taber, R. Tyson, and E. Simonne.: Foliar-applied micronutrients in aquaponics: A guide to use and sourcing. Horticultural Sciences Department, Florida Cooperative Extension Service, Institute of Food and Agricultural Sciences, University of Florida; Publication No. HS1163:1-8, 2010.

15. Yoshioka, T., and T. Saijo.: Photoinhibition and recovery of NH4+ oxidizing bacteria and NO2 - oxidizing bacteria. J. Gen. Appl. Microbiol. 30, 151-166, 1984.

Primljeno: 15. 12.2014

Odobreno: 20.12.2014. 